\title{
Eating Epilepsy in North India: Case Series and Its Management
}

\section{Case Report}

Journal of Epilepsy Research pISSN 2233-6249 / elSSN 2233-6257

Received August 18, 2019

Revised January 8, 2020

Accepted January 24, 2020

Corresponding author:

Atma Ram Bansal, MD

Department of Neurology, Medanta Institute

of Neuroscience, Medanta- The Medicity

Hospital, Sector 38, Gurgaon, Haryana

122001, India

Tel. +919958026324

Fax. +911244141414

E-mail; atmarambansal@yahoo.com

\author{
Pankaj Singh, MD, Atma Ram Bansal, MD, Aniruddha More, MD, Susant Bhuyan, MD, \\ Arun Garg, MD
}

Department of Neurology, Medanta Institute of Neuroscience, Medanta- The Medicity Hospital, Haryana, India

Eating epilepsy is a rare form of reflex epilepsy where seizures are triggered by eating. We describe a case series of 12 such patients presenting to our epilepsy clinic based in North India. Eating epilepsy was noted to have male predominance with focal seizures with impaired awareness. Most of these patients had either temporal or perisylvian localization. Clobazam taken half an hour before meal was found to be an effective add-on therapy in its management. (2019;9:152-156)

Key words: Eating epilepsy, Reflex epilepsy, Clobazam

\section{Introduction}

Reflex epilepsy is a type of epilepsy in which seizures are provoked habitually by external stimulus or uncommonly by internal mental process. ${ }^{1}$ Eating epilepsy (EE) is a distinct subtype of reflex epilepsy, where seizures are triggered by the act of eating. The first case of $\mathrm{EE}$ was described as early as 1967 in which seizures were triggered during meals and even at the mear sight of meal. ${ }^{2}$ This variant though scantly reported in other parts of world, has been widely reported from Indian subcontinent in last 2-3 decades. ${ }^{3,4}$ Seizures usually happen during or few minutes after meals. ${ }^{5}$ Eating is a complex process which starts from thought of food to satisfactory feeling of satiety after eating. It involves many stimuli which may have different pathophysiology in seizure occurrence in patients with $\mathrm{EE}$.

Electroencephalogram (EEG) and functional neuroimaging evidence suggest involvement of complex perisylvian neuronal circuits. ${ }^{6}$ Many of these patients are not well controlled of seizures despite polytherapy. We describe case reports here to present various characteristics of EE in our patient series from North India.

\section{Case Report}

A total of 12 patients out of 1,532 patients presenting to epilepsy clinic were detected to have EE in 18 months (January 2015 to June 2016). Age and duration of seizure onset, seizure semiology and on-going medications, their EEG and magnetic resonance imaging (MRI) brain findings were tabulated as variables (Table 1). A follow up after 6 months was done during their scheduled visit or telephonically for assessing treatment response (Table 2).Categorical variables were summarized using counts and percentages. Quantitative variables were summarized using mean and standard deviation or median and interquartile range (IQR).

Of them, 11 patients (91.7\%) were male. Median age at presentation was 24 years $(21.5,27.5)$ and median age at onset of seizures was 13.5 years $(10.5,23.0)$. None of them had a family history of seizure disorder. Nine patients (75\%) reported 'eating' as the only triggering stimuli. Others (three patients, 25\%) had an additional trigger such as anxiety, while bathing or spontaneously. Majority of the patients (seven patients, 58.3\%) developed seizures either during lunch or dinner. Rest of them (five patients, 41.7\%) had no such predilection to any meal. Semiology of seizures was variable and complex in most of them. Four patients (33.3\%) had aura preceding the events. Most of them (11 patients, 91.7\%) had focal onset seizures. Focal onset impaired awareness seizures were noted in nine of them while focal to bilateral tonic clonic type was present in seven of them. Only one patient (8.3\%) had generalized onset tonic seizures (Table 1).

All patients underwent routine EEG recording during meals. Five of them (41.7\%) had temporal or centrotemporal interictal epileptiform discharges (IEDs) in form of spikes while one of them (8.3\%) had bi- 
Table 1. Demographics, seizure semiology, EEG and neuroimaging of patients with eating epilepsy

\begin{tabular}{|c|c|c|c|c|c|c|c|c|c|c|c|}
\hline No. & $\begin{array}{l}\text { Age } \\
\text { (years) }\end{array}$ & Sex & $\begin{array}{l}\text { Age } \\
\text { of } \\
\text { onset } \\
\text { (years) }\end{array}$ & $\begin{array}{l}\text { Trigger } \\
\text { stimuli }\end{array}$ & $\begin{array}{c}\text { Triggering } \\
\text { meal }\end{array}$ & Seizure semiology & $\begin{array}{l}\text { Type of } \\
\text { seizures }\end{array}$ & $\begin{array}{l}\text { Seizure } \\
\text { frequency } \\
\text { before } \\
\text { clobazam } \\
\text { (per week) }\end{array}$ & $\begin{array}{l}\text { Family } \\
\text { history }\end{array}$ & EEG & $\begin{array}{l}\text { Neuroimag } \\
\text {-ing (MRI } \\
\text { brain) }\end{array}$ \\
\hline 1 & 24 & $M$ & 15 & Eating & $L, D$ & $\begin{array}{l}\text { Aura-Vague uneasiness; } \\
\text { Ictus-Sudden onset staring } \\
\text { followed by manual automatisms } \\
\text { and ictal speech. }\end{array}$ & $\begin{array}{l}\text { Focal onset } \\
\text { impaired } \\
\text { awareness }\end{array}$ & $7-14$ & None & $\begin{array}{l}\text { Frequent left } \\
\text { posterior } \\
\text { temporal IEDs } \\
\text { with secondary } \\
\text { generalization }\end{array}$ & Normal \\
\hline 2 & 28 & M & 21 & Eating & $L, D$ & $\begin{array}{l}\text { Aura-None; Ictus-Sudden } \\
\text { unresponsiveness for few seconds } \\
\text { associated oromandibular } \\
\text { automatisms sometimes is } \\
\text { followed by posturing of all limbs }\end{array}$ & $\begin{array}{l}\text { Focal onset } \\
\text { impaired } \\
\text { awareness, } \\
\text { focal to } \\
\text { bilateral tonic } \\
\text { clonic }\end{array}$ & $7-14$ & None & Normal & $\begin{array}{l}\text { Right } \\
\text { temporal } \\
\text { sclerosis }\end{array}$ \\
\hline 3 & 22 & $\mathrm{M}$ & 10 & Eating & $L, D$ & $\begin{array}{l}\text { Aura-None; Ictus-Behavioral arrest } \\
\text { followed by eyes to one side and } \\
\text { posturing of both upper limbs } \\
\text { (right>left). Sometimes clonic } \\
\text { movement in fingers. }\end{array}$ & $\begin{array}{l}\text { Focal to bilateral } \\
\text { tonic clonic }\end{array}$ & $5-7$ & None & Normal & $\begin{array}{l}\text { Bilateral } \\
\text { perisylvian } \\
\text { gliosis }\end{array}$ \\
\hline 4 & 19 & $\mathrm{M}$ & 8 & Eating & Any & $\begin{array}{l}\text { Aura-Giddiness; Ictus-Fall, tonic } \\
\text { posturing of limbs with salivation. } \\
\text { Followed by prolonged sleepiness. }\end{array}$ & $\begin{array}{l}\text { Generalized } \\
\text { tonic }\end{array}$ & $14-21$ & None & $\begin{array}{l}\text { Left } \\
\text { centro-tempor } \\
\text { al IEDs }\end{array}$ & $\begin{array}{l}\text { Left inferior } \\
\text { frontal } \\
\text { gliosis }\end{array}$ \\
\hline 5 & 14 & M & Birth & $\begin{array}{l}\text { Eating, } \\
\text { anxiety }\end{array}$ & $\begin{array}{l}\text { Any meal, } \\
\text { Fluids }\end{array}$ & $\begin{array}{l}\text { Aura-None; Ictus-Sudden onset } \\
\text { stare with behavior arrest } \\
\text { followed by subtle tonic posturing } \\
\text { of limbs with neck deviation for } \\
\text { few seconds. }\end{array}$ & $\begin{array}{l}\text { Focal to bilateral } \\
\text { tonic clonic }\end{array}$ & $21-28$ & None & $\begin{array}{l}\text { Bilateral } \\
\text { peri-rolandic } \\
\text { spike }\end{array}$ & $\begin{array}{l}\text { Bilateral } \\
\text { perisylvian } \\
\text { gliosis } \\
\text { (left>right) }\end{array}$ \\
\hline 6 & 31 & $\mathrm{M}$ & 27 & $\begin{array}{l}\text { Eating, } \\
\text { spon- } \\
\text { ta- } \\
\text { neous }\end{array}$ & Any & $\begin{array}{l}\text { Aura-None; Ictus-Sudden onset } \\
\text { unresponsiveness, stare, not able } \\
\text { to talk for } 1-2 \text { minutes. }\end{array}$ & $\begin{array}{l}\text { Focal onset } \\
\text { impaired } \\
\text { awareness }\end{array}$ & 1 & None & $\begin{array}{l}\text { Right posterior } \\
\text { head region } \\
\text { and left } \\
\text { temporal } \\
\text { spikes }\end{array}$ & Normal \\
\hline 7 & 27 & $\mathrm{~F}$ & 12 & Eating & $L, D$ & $\begin{array}{l}\text { Aura-Epigastric rising sensation, } \\
\text { heaviness in head; } \\
\text { Ictus-Behavioral arrest wit } \\
\text { spontaneous recovery in lass than } \\
\text { a minute, sometimes develops } \\
\text { tonic clonic movements of right } \\
\text { ULLL followed by all } 4 \text { limbs; post } \\
\text { ictal weakness of right UL for } \\
\text { about 5-10 minutes. }\end{array}$ & $\begin{array}{l}\text { Focal onset } \\
\text { impaired } \\
\text { awareness, } \\
\text { focal to } \\
\text { bilateral tonic } \\
\text { clonic }\end{array}$ & 1 & None & Normal & Normal \\
\hline 8 & 22 & M & 12 & Eating & Any & $\begin{array}{l}\text { Aura-None; Ictus-Sudden staring } \\
\text { look. Oro-mandibular } \\
\text { automatisms for about few } \\
\text { seconds followed by headache } \\
\text { and sleep. Occasionally } \\
\text { progresses to generalized seizures } \\
\text { with tonic clonic movements. }\end{array}$ & $\begin{array}{l}\text { Focal onset } \\
\text { impaired } \\
\text { awareness, } \\
\text { focal to } \\
\text { bilateral tonic } \\
\text { clonic }\end{array}$ & $0.5-1$ & None & Normal & Normal \\
\hline 9 & 51 & M & 31 & Eating & Any & $\begin{array}{l}\text { Aura-Cephalic sensation; } \\
\text { Ictus-Behavioral arrest, stare, } \\
\text { spontaneously recovers to normal } \\
\text { in } 30-40 \text { seconds. No post ictal } \\
\text { confusion. }\end{array}$ & $\begin{array}{l}\text { Focal onset } \\
\text { impaired } \\
\text { awareness }\end{array}$ & $2-3$ & None & Normal & Normal \\
\hline
\end{tabular}


Table 1. Continued

\begin{tabular}{|c|c|c|c|c|c|c|c|c|c|c|c|}
\hline No. & $\begin{array}{l}\text { Age } \\
\text { (years) }\end{array}$ & Sex & $\begin{array}{l}\text { Age } \\
\text { of } \\
\text { onset } \\
\text { (years) }\end{array}$ & $\begin{array}{l}\text { Trigger } \\
\text { stimuli }\end{array}$ & $\begin{array}{c}\text { Triggering } \\
\text { meal }\end{array}$ & Seizure semiology & $\begin{array}{l}\text { Type of } \\
\text { seizures }\end{array}$ & $\begin{array}{l}\text { Seizure } \\
\text { frequency } \\
\text { before } \\
\text { clobazam } \\
\text { (per week) }\end{array}$ & $\begin{array}{l}\text { Family } \\
\text { history }\end{array}$ & EEG & $\begin{array}{c}\text { Neuroimag } \\
\text {-ing (MRI } \\
\text { brain) }\end{array}$ \\
\hline 10 & 25 & $\mathrm{M}$ & 25 & $\begin{array}{l}\text { Eating, } \\
\text { bathing }\end{array}$ & $L, D$ & $\begin{array}{l}\text { Aura-None; Sudden ill-defined } \\
\text { uneasiness, some involuntary } \\
\text { movements over the jaw region } \\
\text { with restlessness for few } \\
\text { seconds followed by loss of } \\
\text { consciousness for } 1-2 \text { minutes. } \\
\text { Sleeps thereafter. }\end{array}$ & $\begin{array}{l}\text { Focal onset } \\
\text { impaired } \\
\text { awareness }\end{array}$ & 0.5 & None & Normal & $\begin{array}{l}\text { Right } \\
\text { frontal } \\
\text { perisylvian } \\
\text { sclerosis }\end{array}$ \\
\hline 11 & 24 & M & 11 & Eating & $L, D$ & $\begin{array}{l}\text { Aura-None. Will complain of } \\
\text { sudden sleepiness during later } \\
\text { part of meals and will doze off } \\
\text { for one minute. Rare episodes } \\
\text { of GTCS in past. }\end{array}$ & $\begin{array}{l}\text { Focal onset } \\
\text { impaired } \\
\text { awareness, } \\
\text { Focal to } \\
\text { bilateral tonic } \\
\text { clonic }\end{array}$ & $3-4$ & None & $\begin{array}{l}\text { Right } \\
\text { centro-tempo } \\
\text { ral IEDs }\end{array}$ & Normal \\
\hline 12 & 21 & M & 18 & Eating & $L, D$ & $\begin{array}{l}\text { Aura-None. Suddenly feels } \\
\text { headache, uneasiness followed } \\
\text { by staring look lasting for } 40-50 \\
\text { seconds. Sometimes induces } \\
\text { vomiting for relief from } \\
\text { uneasiness. Rare episodes } \\
\text { progressing to bilateral tonic } \\
\text { clonic movements with post } \\
\text { ictal confusion. }\end{array}$ & $\begin{array}{l}\text { Focal onset } \\
\text { impaired } \\
\text { awareness, } \\
\text { focal to } \\
\text { bilateral tonic } \\
\text { clonic }\end{array}$ & $4-7$ & None & $\begin{array}{l}\text { Rare bilateral } \\
\text { post head } \\
\text { region IEDs }\end{array}$ & Normal \\
\hline
\end{tabular}

EEG, electroencephalogram; MRI, magnetic resonance imaging; M, male; L, lunch; D, dinner; IEDs, interictal epileptiform discharges; F, female; GTCS, generalized tonic-clonic seizures.

Table 2. Treatment response on change of therapy

\begin{tabular}{|c|c|c|c|c|c|}
\hline No. & $\begin{array}{l}\text { Seizure frequency before } \\
\text { clobazam (per week) }\end{array}$ & Ongoing medications & $\begin{array}{c}\text { New medications added to } \\
\text { old treatment }\end{array}$ & $\begin{array}{l}\text { Seizure frequency after } \\
\text { clobazam (per week) }\end{array}$ & Clobazam benefit \\
\hline 1 & $7-14$ & LVT, OXC & CLB & $7-14$ & No \\
\hline 2 & $7-14$ & VPA, LCM & CLB & $3-4$ & Yes \\
\hline 3 & $5-7$ & CBZ, LVT & CLB & $1-2$ & Yes \\
\hline 4 & $14-21$ & OXC, LVT, PHB & CLB & 7 & Yes \\
\hline 5 & $21-28$ & OXC, LVT & CLB & 0 & Yes \\
\hline 6 & 1 & OXC, LCM & CLB & $1-2$ & No \\
\hline 7 & 1 & OXC, LVT & CLB & 0.06 (1/3-4 months) & Yes \\
\hline 8 & $0.5-1$ & CBZ & CLB & 0.25 & Yes \\
\hline 9 & $2-3$ & VPA, TPM (inadequate dose) & TPM (dose increases) & 0 (none since 20 months) & Not on clobazam \\
\hline 10 & 0.5 & LVT, LCM & CLB & 0 (none since 5 months) & Yes \\
\hline 11 & $3-4$ & PHT & CLB & $0.25-0.75$ & Yes \\
\hline 12 & $4-7$ & VPA & CLB & 0.25 & Yes \\
\hline
\end{tabular}

LVT, levetiracetam; OXC, oxcarbazepine; CLB, clobazam; VPA, valproate; LCM, lacosamide; CBZ, carbamazepine; PHB, phenobarbitone; TPM, topiramate.

lateral posterior head region IEDs. Six patients $(50 \%)$ had normal EEG during eating. Neuroimaging (MRI brain) was abnormal in five patients (41.6\%). Two had bilateral lesions and three had unilateral lesions. Three patients had perisylvian gliosis, one had right frontal lesion and one had right temporal lesion. Eight patients (75\%) had MRI and/or EEG abnormality confined to perisylvian region (Table 1). 
Eleven out of 12 patients were on adequate doses of antiepileptic drugs at presentation. They were started on clobazam, a benzodiazepine antiepileptic in doses of 5 to $10 \mathrm{mg}$ half hour prior to meals. Addition of clobazam, led to reduction in seizure frequency in nine out of 11 patients ( $81.8 \%$ ). Of these nine patients, four became seizure free for many months together. One did not show any response while one had increase in seizure frequency after addition of clobazam. One patient (patient No. 9) improved by optimizing his ongoing antiepileptic drug therapy without addition of clobazam (Table 2).

\section{Discussion}

Eating epilepsy is a rare subtype of reflex epilepsy. Because of unknown reasons it has been widely reported from Indian subcontinent ${ }^{3-8}$ and only scarcely reported as small case series ${ }^{9,10}$ or case reports $^{11-13}$ from other parts of the world. A maximum prevalence of eating epilepsy is $5.6 \%$ of all epilepsy cases, which has been reported from Srilanka. ${ }^{5}$ In our north Indian study, it is noted to be less than $1 \%(0.78 \%, 12$ in 1,532). The world over prevalence of eating epilepsy is considered to be 0.05 to $0.1 \%$ of all epilepsies. ${ }^{11}$ EE has male predominance $e^{3,-10}$ and the usual age of onset of symptoms is 2nd decade. ${ }^{3-6}$ In our case series, we also observed similar clinical characteristics.

Various authors have noted significant heterogeneity in triggers for these seizures. Act of mastication while eating, ${ }^{2}$ oesophageal stimulation, ${ }^{14}$ satisfactory feeling of having meal, ${ }^{15}$ timing of the meal, ${ }^{10,16}$ sight, smell or even thought of food ${ }^{17}$ have been described in different groups of patients worldwide. Heavy carbohydrate rich meals traditionally consumed in Indian subcontinent particularly during lunch and dinner could be one of the factors contributing to its high prevalence in predisposed individuals. ${ }^{3,8}$

Since these seizures occur in relation to food, EE is almost exclusively a symptomatic focal epilepsy. ${ }^{11}$ Multiple case reports and case series have reported focal aetiologies like cortical malformation, ${ }^{13,18}$ hypoxic brain damage, ${ }^{12}$ meningoencephalitis ${ }^{19}$ or space occupying lesions ${ }^{6,9,20}$ involving temporal lobe ${ }^{8,12,16,20}$ and perisylvian area. ${ }^{6,9,19}$ Sometimes they may not have any structural lesions on neuroimaging ${ }^{4,9}$ In our series majority of the patients had either MRI or EEG abnormality localizing to perisylvian region. Apart from these acquired causes, cases of defined genetic etiology in pediatric population with mutations in SYNGAP1 gene ${ }^{21}$ and duplication of MECP2 gene ${ }^{22}$ have been described. Cluster of familial cases with EE have also been reported by Senanayake ${ }^{23}$ and Yacubian et al. ${ }^{24}$
The predominant semiology was sudden unresponsiveness, staring look with or without subtle tonic posturing of limbs. Eyelid myoclonia with short absences with tonic, atonic or myoclonic movements of limbs or trunk has been described in intellectually disabled children with SYNGAP1 mutation, especially around meals. ${ }^{21}$ One third of our patients described nonspecific aura prior to seizures. The aura was described as light or heavy headedness, uneasiness, or epigastric sensation suggesting a temporal lobe onset. The seizures characteristically are focal onset with impaired awareness. ${ }^{7}$ These focal seizures may generalize to tonic, atonic or myoclonic seizures infrequently. ${ }^{25}$ Our 11 out of 12 patients had focal onset seizures.

IEDs have diagnostic as well as localization significance in these patients. Most studies have found focal IEDs at temporal and centro-temporal areas of brain, ${ }^{3,10,16}$ in up to $70 \%$ of patients. ${ }^{3}$ Continuous EEG recording during meals increases the frequency of these discharges and could also precipitate ictus. Ictal discharges consist of focal slowing or fast beta activity during these episodes. ${ }^{6}$ Ictal and interictal EEG in most of these patients showed fronto-central or temporal discharges ${ }^{3,6,9-11,12}$ even in MRI negative patients. Our six patients had a similar distribution of IEDs. Children with SYNGAP1 mutation have shown short duration $3 / \mathrm{sec}$ irregular high amplitude spike and wave discharges in temporal and occipital areas. ${ }^{21}$

Positive neuroimaging findings such as gliosis, encephalomalacia or space occupying lesions have been noted either at temporal lobe $e^{9,12,16,20}$ or perisylvian areas ${ }^{6,18,19}$ in some of the patients irrespective of the side involved. Our neuroimaging positive patients also had gliosis either at perisylvian area or inferior frontal and temporal lobes. These locations represent opercular area which innervates facial, pharyngeal, masticatory, tongue, laryngeal and branchial muscles. Ictal SPECTand EEG may be of help in localization and determining the extent of lesion ${ }^{5,19}$ specially in MRI negative patients.

The studies suggest eating to be a complex process which leads to activation of opercular cortex and generation of multiple efferent sensory. Investigators have suggested two different type of syndromes. The one with involvement of temporo-limbic region has reflex eating seizures from onset of epilepsy. Triggers usually constitute gustatory, olfactory, autonomic and emotional stimuli. Seizures in this syndrome may occur during any time of meal. The other syndrome involving extralimbic/suprasylvian region (extratemporal) which precipitates reflex eating seizures in previously existing epileptic disorder. Seizures usually precipitate during first few minutes of a meal because of proprioceptive sensory stimuli from complex lingual, buccal and pharyngeal movements. ${ }^{10}$ These sensory stimuli lead to recruitment of 
epileptogenic neurons triggering a critical mass of cortex to precipitate seizures. ${ }^{26}$ Recently it has been suggested that hyperexcitability of perisylvian/opercular region (including insular cortex) leads to EE irrespective of the side of lesion. ${ }^{6,25}$ Three fourth of patients in our study had perisylvian electrographic or neuroimaging localization.

Available literature suggests variable treatment response ranging from good control ${ }^{3,9}$ to treatment refractory EE. ${ }^{10}$ Clobazam was found to be useful in less than $10 \%$ of a large Srilankan study. ${ }^{3}$ We used clobazam in 11 patients. Patients were asked to consume $5 \mathrm{mg}$ or $10 \mathrm{mg}$ of clobazam half hour prior to meal in addition of their pre-existing antiepileptic drugs in adequate doses. On 6 months follow up, nine of 11 patients had responded with decrease in number of seizures. Four of these showed excellent response and became seizure free for months together. Clobazam has also been found effective in patients with another form of reflex seizures known as hot water epilepsy. ${ }^{27}$ However, none of our patients was on monotherapy with clobazam. Clobazam has GABA-A agonist action similar to many other antiepileptic drugs. The precise mechanism of clobazam for its role in EE is not known. Though good response to clobazam addition was seen, we cannot suggest its efficacy as monotherapy. A bigger study with larger sample size and long term follow up may help to evaluate its efficacy.

\section{References}

1. Striano S, Coppola A, del Gaudio L, Striano P. Reflex seizures and reflex epilepsies: old models for understanding mechanisms of epileptogenesis. Epilepsy Res 2012;100:1-11.

2. Scollo-Lavizzari G, Hess R. Sensory precipitation of epileptic seizures. Report on two unusual cases. Epilepsia 1967;8:157-61.

3. Senanayake N. 'Eating epilepsy'--a reappraisal. Epilepsy Res 1990;5:74-9.

4. Jagtap S, Menon R, Cherian A, Baheti N, Ashalatha R, Thomas SV. "Eating" epilepsy revisited- an electro-clinico-radiological study. J Clin Neurosci 2016:30:44-8.

5. Seneviratne $U$, Seetha $T$, Pathirana R, Rajapakse P. High prevalence of eating epilepsy in Sri Lanka. Seizure 2003;12:604-5.

6. Patel M, Satishchandra P, Saini J, Bharath RD, Sinha S. Eating epilepsy: phenotype, MRI, SPECT and video-EEG observations. Epilepsy Res 2013; 107:115-20.

7. Ahuja GK, Pauranik A, Behari M, Prasad K. Eating epilepsy. J Neurol 1988;235:444-7.

8. Mandal DK, Bandyopadhyay S, Tarafdar J, et al. Eating epilepsy: a study of twenty cases. I Indian Med Assoc 1992;90:9-11.
9. Gujjar AR, Jacob PC, Ramanchandiran N, Al-Asmi A. Eating epilepsy in Oman: a case series and report on the efficacy of temporal lobectomy. Sultan Qaboos Univ Med J 2013;13:156-61.

10. Kokes U, Baykan B, Bebek N, Gurses C, Gokyigit A. Eating epilepsy is associated with initial precipitating events and therapy resistance. Clin EEG Neurosci 2013;44:161-6.

11. Rémillard GM, Zifkin $B G$, Andermann F. Seizures induced by eating. Adv Neurol 1998;75:227-40.

12. Loreto $V$, Nocerino C, Striano P, D' Aulos F, Boccella P, Striano S. Eating epilepsy. Heterogeneity of ictal semiology: the role of video-EEG monitoring. Epileptic Disord 2000;2:93-8.

13. Verdú A, Ruiz-Falco ML. Eating seizures associated with focal cortical dysplasia. Brain Dev 1991;13:352-4.

14. Forster FM. Epilepsy associated with eating. Trans Am Neurol Assoc 1971;96:106-9.

15. Cirignotta F, Marcacci G, Lugaresi E. Epileptic seizures precipitated by eating. Epilepsia 1977;18:445-9.

16. Nagaraja D, Chand RP. Eating epilepsy. Clin Neurol Neurosurg 1984;86: 95-9.

17. El Bouzidi K, Duncan S, Whittle IR, Butler CR. Lesional reflex epilepsy associated with the thought of food. Neurology 2010;74:610-2.

18. Kishi T, Moriya M, Kimoto $Y$, Nishio $Y$, Tanaka T. Congenital bilateral perisylvian syndrome and eating epilepsy. Eur Neurol 1999;42:241-3.

19. Mateos V, Salas-Puig J, Campos DM, Carrero V, Andermann F. Acquired bilateral opercular lesions or Foix-Chavany-Marie syndrome and eating epilepsy. J Neurol Neurosurg Psychiatry 1995;59:559-60.

20. Manyam SC, Kung DH, Rhodes LB, Newmark ME, Friedman DE. Unilateral opercular lesion and eating-induced seizures. Epileptic Disord 2010;12: 309-13.

21. von Stülpnagel C, Hartlieb T, Borggräfe I, et al. Chewing-induced reflex seizures ("eating epilepsy") and eye closure sensitivity as a common feature in pediatric patients with SYNGAP1 mutations: review of literature and report of 8 cases. Seizure 2019;65:131-7.

22. de Palma L, Boniver C, Cassina M, et al. Eating-induced epileptic spasms in a boy with MECP2 duplication syndrome: insights into pathogenesis of genetic epilepsies. Epileptic Disord 2012;14:414-7.

23. Senanayake N. Familial eating epilepsy. J Neurol 1990;237:388-91.

24. Yacubian EMT, Skaff $R$, Garzon $E$, et al. Seizures induced by eating in a family. In: Wolf $P$, Inoue $Y$, Zifkin $B$, ed. Reflex epilepsies: progress in understanding. Montrouge: John Libbey Eurotext, 2004;123-33.

25. Narayan S, Nair P, Murgai A, Sharma P, Wadwekar V. Eating epilepsy, redefining the semiology (P07.173). Neurology 2013;80(7 Supplement): P07.173.

26. Wieser HG. Seizure induction in reflex seizures and reflex epilepsy. Adv Neurol 1998;75:69-85.

27. Satishchandra P, Sinha S. Hot-water epilepsy: from bench to bedside. Ann Indian Acad Neurol 2013;16:137-43. 